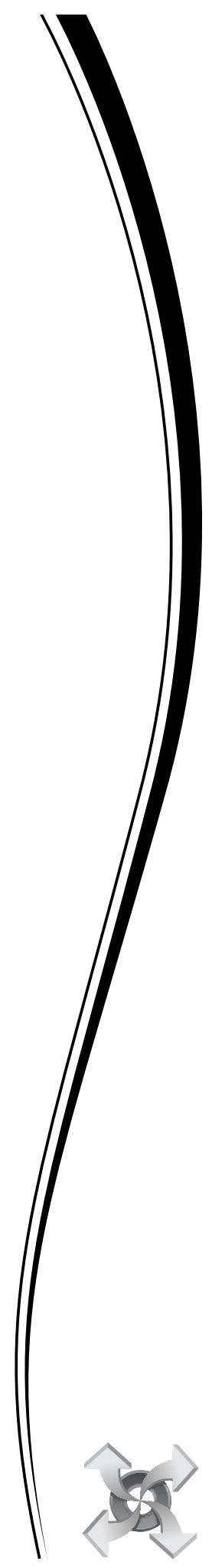

Jurnal Ekonomi, Manajemen dan Akuntansi Islam I M A NENS I Volume 1

Nomor 1

Halaman 1-74

Malang, September 2013 ISSN 2339-1847

\title{
MENGAPA PERBANKAN SYARIAH MASIH DISAMAKAN DENGAN PERBANKAN KONVENSIONAL?
}

\author{
Virginia Nur Rahmanti \\ Universitas Brawijaya. J1. MT. Haryono 165, Malang. \\ Email: vnurrahmanti@yahoo.co.id
}

\begin{abstract}
Abstrak: Mengapa Perbankan Syariah Masih Disamakan dengan Perbankan Konvensional? Dewasa ini atmosfer syariah semakin digemari masyarakat Indonesia. Namun sayangnya esensi syariah tampaknya belum terintegrasi di dalam akad-akad transaksi syariah. Beberapa penelitian mengungkapkan bahwa terdapat beberapa factor yang memicunya. Penelitian ini menggunakan metodologi interpretif dengan metode fenomenologi. Kesimpulan dari penelitian menunjukkan bahwa terdapat dua faktor yang memicu mengapa perbankan syariah masih diidentikkan dengan perbankan konvensional, yaitu karena faktor standard an SDM. Standar yang berupa PSAK syariah dinilai belum sepenuhnya syar'i dan implementatif. Alasan kedua terkait dengan pemahaman SDM perbankan syariah tentang syariah. Sejauh yang mereka pahami, syariah berarti sekedar bebas riba. Inilah yang menyebabkan jarak antara kajian teori dan praktik menjadi semakin lebar.
\end{abstract}

\begin{abstract}
Why Islamic Banking is Still Equatedto Conventional Banking? Nowadays, shariah atmosphere is increasingly popular in Islamic society. Unfortunately it seems that it is not yet integrated the essence of sharia in any contract of Islamic transactions. Some studies reveal that there are several factors which cause such phenomenon. This research employed interpretive paradigm with phenomenological method. The study indicates that there are two factors that trigger why Islamic banking is still equated to conventional banking, namely standard and human resource factors. PSAK is not yet fully syar'i and implementative. The second reason is associated with human resource understanding of Islamic shariah banking. As far as they understand, shariahis simply free from riba. These causethe enlarging gap between theory and practice.
\end{abstract}

Kata kunci: implementatif, standar akuntansi syariah, SDM

Lahirnya sistem syariah dilatarbelakangi oleh semakin bekembangnya masyarakat muslim di Indonesia yang diiringi dengan kesadaran mereka terhadap ketidakadilan skema perbankan konvensional. Alasan lain diungkapkan oleh Setiawan (2006) bahwa pergeseran sistem konvensional ini disebabkan pula oleh keinginan perubahan terhadap sistem sosio politik dan ekonomi yang berlandaskan prinsip-prinsip Islam dan kepribadian Islam yang lebih kuat, sekaligus sebagai upaya reformasi makro ekonomi dan reformasi struktural dalam sistem negara-negara muslim. Mereka menginginkan keluar dari jeratan pengaruh sistem kapitalisme. Keinginan umat Islam akan lahirnya bank yang beroperasi sesuai dengan prinsip-prinsip syariah Islam (bank syariah) sesungguhnya sudah sejak lama digagas oleh para tokoh dan cendikiawan muslim Indonesia,yaitu muncul sejak tahun 1930-an. Seiring dengan semakin lamanya kontroversi mengenai hukum bunga bank di kalangan ulama, gagasan mendirikan Bank Syariah semakin sering disuarakan umat Islam di Indonesia. Namun demikian, ternyata upaya melahirkan sebuah sistem baru tidak semudah membalik telapak tangan. Hambatan ini terbukti pada tahun 1958 salah 
seorang ekonom terkemuka Indonesia, $\mathrm{Mu}-$ hammad Hatta justru dengan tegas menolak gagasan untuk mendirikan Bank Islam yang bebas bunga, karena menurutnya bank tidak akan langgeng tanpa menerapkan bunga (Muhammad 2005: 45).

Meskipun tergolong terlambat dalam melahirkan sistem syariah, namun fenomena ini tidak menyurutkan semangat para muslim untuk tetap gencar menyuburkan praktik pebankan syariah di Indonesia. Disampaikan pada BI outlook 2012 bahwa selama tahun 2012, perbankan syariah Indonesia mengalami tantangan yang cukup berat dengan mulai dirasakan dampak melambatnya pertumbuhan perekonomian dunia yang menyebabkan pertumbuhan ekonomi Indonesia tidak setinggi yang diharapkan, walaupun Indonesia masih termauk Negara yang masih mengalami pertumbuhan ekonomi stabil di dunia. Namun demikian, sampai pada tahun 2012peningkatan kuantitas Lembaga Keuangan Syariah (LKS) baik yang berlevel makro maupun mikro (LKMS) tidak bisa diremehkan lagi ${ }^{1}$.

Kabar baik ini diiringi oleh semangat dewan penyusun standar syariah yang mulai menggeliat kontribusi pemikirannya, terlebih ketika tersiar kabar bahwa perbankan syariah mampu bediri tegak di tengah pusaran badai krisis global yang terjadi pada tahun 2008 silam. Sistem keuangan Islam diharapkan mampu menyuntikkan disiplin sekaligus mendorong untuk terpenuhinya regulasi dan supervisi yang prudensial pada industri keuangan (Setiawan 2006).Fenomena-fenomena inilah yang kemudian menyuburkan bank-bank Islami tumbuh semakin banyak di seluruh penjuru dunia khususnya sepanjang 30 tahun terakhir ${ }^{2}$. Pada usianya

1 Selama periode tahun 2012, jumlah Bank Umum Syariah (BUS) dan Unit Usaha Syariah (UUS) sampai dengan Oktober 2012 tidak mengalami perubahan, namun demikian jumlah jaringan kantor meningkat. Meskipun dengan jumlah BUS (11 buah) maupun UUS (24 buah) yang sama, namun pelayanan kebutuhan masyarakat akan perbankan syariah menjadi semakin meluas yang tercermin dari bertambahnya Kantor Cabang dari sebelumnya sebanyak 452 menjadi 508 Kantor, sementara Kantor Cabang Pembantu (KCP) dan Kantor Kas (KK) telah bertambah sebanyak 440 kantor pada periode yang sama (Oktober 2012, yoy). Secara keseluruhan jumlah kantor perbankan syariah yang beroperasi sampai dengan bulan Oktober 2012 dibandingkan tahun sebelumnya meningkat dari 1.692 kantor menjadi 2.188 kantor.

2 M. Umer Capra \& Habib Ahmed, "Corporate Governance in Islamic Financial Institution", (Jedah: Ocasional Paper IDB, 2002), hal. 1. yang ke-20 tahun ini, ternyata eksistensi LKS tidak lepas dari kritikan masyarakat. Sebagian besar dari mereka masih menyimpulkan bahwa mekanisme perbankan syariah tidak berbeda dengan konvensional (Zaidi 20123; Primasari 2010). Lebih jauh mereka mengungkapkan bahwa ternyata LKS hanyalah institusi konvensional yang menggunakan bahasa Arab untuk indetifikasi produk dan transaksinya.

Peran Sumber Daya Manusia (SDM) yang berkualitas dalam upaya membangun Negara adalah asset utama. Asset berwujud yang dimiliki entitas seperti bangunan, peralatan, mesin produksi, akan menjadi modal yang tidak akan memberikan kontribusi maksimal jika tidak didukung dengan kualitas SDM. Seperti yang diungkapkan oleh Ulrich (1998) yang dikutip oleh Nurhayati (2001) bahwa knowledge yang ada pada manusia merupakan salah satu item yang digunakan untuk meningkatkan daya saing baik dalam menjual ide (selling idea). Telah banyak contoh Negara yang berhasil bangkit karena kebangkitan kualitas SDM mereka. Ambil contoh China yang pada akhirnya mampu menjadi Negara raksasa karena keberhasilannya dalam memperbaiki kualitas masyarakat akademisi dengan mendorong mereka belajar ke Negara lain di dunia ${ }^{4}$. Dengan kata lain, kemajuan suatu peradaban ditentukan oleh faktor kualitas masyarakatnya.

Tema tentang SDM ini pulalah yang sepertinya menjadi salah satu alasan utama mengapa syariah belum bisa berkembang secara maksimal di Indonesia (Affianta 2011; Sulistiyo 2010; Anggadini 2010). Minimnya pemahaman tentang mekanisme transaksi keuangan syariah dan lebih lagi dipupuk dengan rasa acuh untuk berusaha memahami mekanisme syariah, pada akhirnya akan menghasilkan sebuah simpulan masyarakat bahwa ternyata praktik perbankan syariah tidak berbeda dengan konvensional. SDM yang dimaksudkan dalam penelitian ini meliputi praktisi (pengelola LKS), dewan penyusun standar, dan akademisi. Dapat kita bayangkan jika ketiga pihak yang memegang peranan penting dalam perkembangan syari-

3 Diunduh dari Tabloid Syariah pada 3 Mei 2012 de-ngan situs http://www.syariah.info/2012/02/08/)

4 Disampaikan dalam satu acara kuliah tamu Leaning From China yang disampaikan oleh Kym Fraser dari Australia pada 1 Mei 2012 betempat di Fakultas Ekonomi dan Bisnis Universitas Brawijaya. 
ah kurang memahami hakikat syariah serta akad transaksi syariah yang mengikutinya, maka dapat dipastikan perbankan syariah di negeri ini tidak akan mampu berkembang pesat untuk bersaing dengan Negara muslim lainnya.

Menyoroti masalah perbankan syariah, tentunya tidak dapat terlepas dari akuntansi syariah sebagai dasar pedoman pencatatan dan pelaporan. Secara umum, sebagian besar masyarakat baik praktisi maupun akademisi menyimpulkan bahwa akuntansi syariah adalah hasil duplikasi akuntansi konvensional (Harahap 2001; Kamayanti dan Parwita 2008). Di Indonesia, konsep akuntansi syariah yang mencakup pelaporan dan akad-akad transaksi tertuang dalam PSAK syariah yang diawali dari diluncurkannya standar PSAK syariah no.59 tentang Akuntansi Perbankan Syariah tanggal 1 Mei 2002 dan berlaku pada 1 Januari 2003. Lima tahun kemudian, standar ini digantikan oleh PSAK syariah 101-106 pada 27 Juni 2007 dan berlaku aktif pada 1 Januari 2008. Lahirnya PSAK syariah 101-106 diharapkan mampu menjadi pedoman bagi praktisi lembaga keuangan syariah dalam menjalankan transaksi muamalah sekaligus menyusun laporan keuangannya. Sayangnya dalam dunia praktik, PSAK syariah sepertinya hanyamenjadi standar "langit", bukan "membumi" layaknya standar teknis. Hal ini ditunjang dengan minimnya pemahaman mayoritas praktisi terhadap mekanisme perbankan syariah sertaminimnya keahlian (skill) dalam hal menyusun laporan keuangan membuat standar tersebut terbukti tidak dapat diterapkan seperti yang diharapkan. Alhasil hanya bank umum syariah yang beroperasi pada level menengah ke ataslah yang menjadi konsumen standar PSAK syariah tersebut. Dengan kata lain, PSAK syariah tidak implementatif bagi LKMS.

Dalam penelitian ini, saya ingin mengetahui faktor apakah yang menjadi penghambat perbankan syariah, sehingga belum mampu berkembang maksimal sampai saat ini. Diharapkan dari penelitian ini dapat menjadi masukan baik bagi akademisi maupun praktisi untuk mencari solusi, agar perkembangan perbankan syariah dapat berkembang pesat mengingat pentingnya peran perbankan syariah dalam perputaran ekonomi global.

Terma syari'ah berarti jalan yang lurus, jalan yang lempang tidak berkelok-kelok, juga berarti jalan raya. Kemudian penggu- naan kata syariah ini bermakna peraturan, adat kebiasaan, undang-undang dan hukum. Lebih lanjut, syariah Islam berarti segala peraturan agama yang telah ditetapkan Allah SWT untuk umat Islam, baik dari Al Qur'an maupun sunnah Rasulullah SAW yang berupa perkataan, perbuatan maupun takrir (penetapan atau pengakuan). Syariah meliputi hukum-hukum Allah bagi seluruh perbuatan manusia tentang halal, haram, makhruh, sunat, dan mubah. Namun demikian, antara syariah dan fiqh jelas memiliki perbedaan.

Syariah bukan berarti mencakup hubungan manusia dengan Tuhan saja, melainkan juga dengan sesama manusia. Djafar (1993: 21-25) memaparkan ruang lingkup syariah sebagai berikut:

a. Hubungan manusia dengan Tuhannya secara vertikal, melalui ibadah, seperti: shalat, puasa, zakat, haji dan sebagainya.

b. Hubungan manusia muslim dengan saudaranya yang muslim, dengan silaturahmi, saling mencintai, tolong menolong dan bantu membantu di antara mereka dalam membina keluarga dan membangun masyarakat mereka.

c. Hubungannya dengan sesama manusia, dengan tolong menolong dan bekerja sama, dalam meningkatkan taraf hidup dan kehidupan masyarakat secara umum dan pedamaian yang menyeluruh.

d. Hubungannya dengan alam lingkungan khususnya, dan alam semesta pada umumnya, dengan jalan melakukan penyelidkan tentang hikmah ciptaan Allah SWT untuk kemakmuran dan kesejahteraan umat manusia seluruhnya.

e. Hubungannya dengan kehidupan, dengan jalan berusaha mencari karunia Allah SWT yang halal, dan memanfaatkannya di jalan yang halal pula, sebagai tanda kusyukuran kepada-Nya, tanpa tabdzir atau bakhil, atau penyalahgunaan atas nikmat dan karunia Allah SWT itu.

Dari perincian di atas, dapat disimpulkan bahwa syariah bukan hanya berkaitan dengan riba semata, namun lebih luas dari itu. Habluminallah dan habluminannas merupakan suatu syarat yang harus dipenuhi untuk bisa dikatakan syariat telah dilaksanakan. 
Tabel 1. Perbedaan Bank Syariah dengan Bank konvensional

\begin{tabular}{cll}
\hline No. & \multicolumn{1}{c}{ Bank Syariah } & \multicolumn{1}{c}{ Bank Konvensional } \\
\hline 1 & $\begin{array}{l}\text { Melakukan investasi -investasi yang halal } \\
\text { saja }\end{array}$ & Investasi yang halal dan haram \\
2 & $\begin{array}{l}\text { Berdasarkan prinsip bagi hasil, jual beli } \\
\text { atau sewa }\end{array}$ & Memakai perangkat bunga \\
3 & $\begin{array}{l}\text { Profit dan falah oriented } \\
4\end{array}$ & $\begin{array}{l}\text { HUbungan nasabah dalam bentuk } \\
\text { kemitraan }\end{array}$ \\
5 & $\begin{array}{l}\text { Penghimpunan dan penyaluran dana } \\
\text { harus sesuai dengan fatwa dewan } \\
\text { pengawas syariah }\end{array}$ & $\begin{array}{l}\text { Hubungan dengan nasabah dalam } \\
\text { bentuk hubungan debitur-debitur }\end{array}$ \\
\end{tabular}

Dalam pelaksanaannya, penerapan akuntansi syariah tidak dapat terlepas dari prinsip-prinsip syariah. Prinsip dalam transaksi syariah menurut AAOIFI terbagi menjadi lima (Nurhayati 2011), yaitu pertama, persaudaraan (ukhuwah), yang berarti bahwa transaksi syariah menjunjung tinggi nilai kebersamaan dalam memperoleh manfaat, sehingga seseorang tidak boleh mendapatkan keuntungan di atas kerugian orang lain. Prinsip ini didasarkan atas prinsip saling mengenal (ta'aruf), saling memahami (tafahum), saling menjamin (takaful), saling bersinergi dan saling beraliansi (tahaluf). Kedua, keadilan ('adalah), yang berarti selalu menempatkan sesuatu hanya pada yang berhak dan sesuai dengan posisinya. Realisasi prinsip ini dalam bingkai aturan muamalah adalah melarang adanya unsurunsur yang meliputi: Riba/bunga dalam segala bentuk dan jenis, baik riba nasiah atau fadhl. Riba sendiri diterjemahkan sebagai tambahan pada pokok piutang yang dipersyaratkan dalam transaksis pinjam meminjam serta derivasinya dan transaksi tidak tunai lainnya, atau transaksi antar barang, termasuk pertuakran uang sejenis secara tunai maupun tangguh dan yang tidak sejenis secara tidak tunai; Kezaliman, baik terhadap diri sendiri, orang lain atau lingkungan. Kezaliman diterjemahkan memberikan sesuatu tidak sesuai ukuran, kualitas dan temponya, mengambil sesuatu yang bukan haknya dan memperlakukan sesuatu tidak sesuai tempatnya/posisinya; Judi, atau bersikap spekulatif dan tidak berhubungan dengan produktivitas (maysir); unsur ketidakjelasan, manipulasi dan eksploitasi informasi serta tidak adanya kepastian pelaksanaan akad, seperti gharardan haram/ segala unsur yang dialrang tegas dalam $\mathrm{Al}$ Qur'an dan As-Sunah, baik dalam barang/ jasa atau pun aktivitas operasional terkait. Ketiga, Kemaslahatan (maslahah), yaitu se- gala bentuk kebaikan dan manfaat yang berdimensi duniawi dan ukhrawi, material dan spiritual, serta individual dan kolektif. Keempat adalah keseimbangan (tawazun), yaitu keseimbangan antara aspek material dan spiritual, antara aspek privat dan publik, antara sektor keuangan dan sektor riil, antara bisnis dan sosial serta antara aspek pemanfaatan serta pelestarian. Prinsip syariah terakhir adalah universalisme (syumuliyah), dimana esensinya dapat dilakukan oleh, dengan dan untuk semua pihak yang berkepentingan tanpa membedakan (rahmatan lil alamin). Dapat disimpulkan bahwa skema syariah bukan berarti tansaksi tanpa riba, namun lebih luas daripada itu seperti pada penjelasan di atas 5 .

Pada dasarnya, terdapat perbedaan substansial antara mekanisme perbankan syariah dan konvensional.Fajarningtyas, et al. 2009 memaparkan bahwa perbedaan pertama terletak pada operasional perbankan syariahyang menerapkan bagi hasil keuntungan dan risiko (profit and loss sharing) sedangkan konvensional menggunakan system bunga. Kedua, jika dilihat pada istilah yang digunakan oleh bank umum, terma pembiayaan disebut loan atau pinjaman, sementara di bank syariah disebut financing atau pembiayaan (Nasution 2003). Artinya pada bank umum pemberian pembiayaan lebih didasarkan pada kerjasama transaksi (untung-rugi), sedangkan pada bank syariah lebih didasarkan pada kerjasama kemitraan.

5 Disampaikan pula oleh Yuslam Fauzi, Dirut BSM dalam tulisannya yang bertajuk " Mengejar Ketertinggalan Ekonomi dengan Perbankan Syariah" bahwa "apapun yang ada dalam sistem perbankan syariah harus bertaqwa kepada Allah SWT, bukan hanya sekadar menjalankan perbankan agar bebas riba, spekulasi, ataupun judi”. Diunduh pada 3 Mei 2012 (http://munas.ldii. or.id/berita/yuslam-fauzi-direktur-utama-bank-syariahmandiri-\%E2\%80\%9Cmengejar-ketertinggalan-ekonomi-dengan-perbankan-syariah\%E2\%80\%9D). 
Sedangkan balas jasa yang diberikan atau diterima pada bank umum berupa bunga (interest loan atau deposit) dalam prosentase pasti. Sementara pada bank syariah dengan sistem syariah, hanya memberi dan menerima balas jasa berdasarkan perjanjian (akad) bagi hasil. Sumber lain,Antonio(2001) dalam Thamrin, Liviawati, dan Wiyati (2011), menjelaskan pula tentang perbedaan bank syariah dan konvensional seperti yang tertera pada tabel 1 berikut ini:

Terlihat dalam tabel di atas, bahwa perbankan konvensional sangat kapitalis. Model akuntansi konvensional pada dasarnya masih memuat ide barat (Muhammad 2003). Pada masa sebelum munculnya akuntansi syariah, model akuntansi konvensional dianggap sebagai sistem pencatatan keuangan yang paling baik di masyarakat. Menurut Muhammad (2004), hal ini terjadi karena adanya eksportasi teknologi akuntansi (yaitu: teknik, institusi dan konsep dari asosiasi profesional yang sangat dominan) melalui kolonisasi, pendidikan, pengembangan perdagangan dan usaha harmonisasi internasional khususnya di negara islam yang sedang berkembang di dunia. Internalisasi akuntansi konvensional melalui bidang pendidikan inilah yang gencar dilakukan di Indonesia, sehingga calon pemikir muda telah terinfeksi oleh suntikan pemikiran ide barat tanpa diberikan ruang untuk berfikir secara lebih kritis.

Beberapa permasalahan akuntansi konvensional muncul dari hasil analisis pemikir muslim yang mulai gerah dengan konsep akuntansi konvensional yang memuat nilai kapitalis. Muhammad (2004) menyampaikan bahwa konsep dan nilai mendasar akuntansi konvensional saat inikontradiktif dengan masyarakat Islam, karena salah satu alasannya masih menggunakan sistem bunga atau riba. Permasalahan kedua adalah terkait dengan rasionalisme yang berhubungan dengan sifat manusia yang cenderung mementingkan dirinya sendiri dan upaya maksimalisasi kekayaan dimana keduanya bertentangan dengan kepentingan kolektif masyarakat luas. Selain dua hal tersebut, permasalahan yang lebih besar dalam perspektif rasionalisme adalah pemisahan agama dari aktivitas ekonomi. Inilah yang terjadi pada akuntansi konvensional yang disadari atau tidak, dalam implementasinya telah memisahkan di antara keduanya. Permasalahan terakhir, terletak pada efisiensi alokasi sumber daya yang didasarkan pada mekanisme pasar (Muhammad 2004) yang awalnya diyakini dapat meningkatkan pertumbuhan ekonomi dan penciptaan kekayaan, namun kenyataannya telah gagal dipenuhi oleh akuntansi konvensional yang justru memicu konflik dalam masyarakat. Senada dengan yang disampaikan oleh $\mathrm{Mu}-$ hammad di atas, Hines (1992: 328) yang dikutip oleh Triyuwono (2003) menyampaikan bahwa :

"The language of accounting is the arch-communicators and social constructor of unbalanced Yang consciousness, society, and environment...it is hard, dry, impersonal, objective, explicit, outer-focus, action-oriented, analytic, dualistic, quantitative, liner, rationalist, reductionist and materialist.

Dari pandangan Hines di atas terlihat bahwa karakter akuntansi menjadi "keras," "rasionalis", "impersonal," dan "materialis." Karakter inilah yang dipancarkan oleh akuntansi modern melalui accounting information (Triyuwono 2002).

PSAK syariah yang petama kali diluncurkan pada tahun 2007, terdiri dari 6 nomor yaitu nomor 101 tentang Penyajian Laporan Keuangan Syariah; nomor 102 tentang Akuntansi Murabahah; nomor 103 tentang Akuntansi Salam; nomor 104 tentang Akuntansi Istishna' ; nomor 105 tentang Akuntansi Mudharabah dan terakhir nomor 106 tentang Akuntansi Musyarakah. Standar Akuntansi Keuangan atau disebut juga General Accepted Accounting Principle adalah aturan tentang metode penyusunan laporan keuangan yang berlaku di Negara Amerika. Berbeda dengan Indonesia, PSAK perbankan syariah merupakan salah satu standar akuntansi keuangan yang mengatur tentang penyusunan laporan keuangan bagi lembaga keuangan syariah. PSAK ini sebagian besar diambil dari standar yang dikeluarkan oleh AAOIFI.

Standar akuntansi syariah ini disusun dengan harapan mampu menjadi pedoman bagi lembaga keuangan syariah yang lahir sebagai terobosan dari praktik akuntansi konvensional (Harahap 2001). Keberadaan Bank Syariah kini semakin berkembang yang ditandai dengan lahirnya bank syariah seperti Bank Syariah Mandiri, Bank Syariah dibawah bank konvensional seperti BNI, BCA, Bank Mega, Bank Bukopin, BRI dan beberapa bank syariah lainnya. 
Standar syariah PSAK dinilai masih banyak mengadopsi kerangka dan standar yang dikeluarkan oleh Accounting and Auditing Organizations for Islamic Financial Institutions (AAOIFI 1998) yang berpusat di Manama Bahrain. Proses penyusunan kedua standar ini juga masih beranjak dari kerangka akuntansi konvensional. Berikut dipaparkan lebih lanjut tentang standar produk IAI, yaitu Kerangka Dasar Penyusunan dan Penyajian Laporan Keuangan Bank Syariah Pernyataan Standar Akuntansi Keuangan (PSAK) Akuntansi Perbankan Syariah (Harahap 2001).

Standar yang digunakan oleh IAI ini masih merujuk pada standar akuntansi konvensional (Gambling dan Karim 1991; Khan 1994; Adnan dan Gaffikin 1998). Hal ini terlihat dari aktivitas mereka yang hanya memberikan tambahan poin-poin tertentu dari akuntansi konvensional, namun tidak melakukan perubahan substansial atas standar akuntansi konvensional. Penilaian mereka menganggap bahwa tidak ada yang perlu ditolak dari standar akuntansi konvensional.

Aliran akuntansi pragmatis menurut Mulawarman (2008) menganggap beberapa konsep dan teori akuntansi konvensional dapat digunakan dengan beberapa modifikasi. Modifikasi dilakukan untuk kepentingan pragmatis seperti penggunaan akuntansi dalam perusahaan Islami yang memerlukan legitimasi pelaporan berdasarkan nilai-nilai Islam dan tujuan syariah. Akomodasi akuntansi konvensional tersebut memang terpola dalam kebijakan akuntansi seperti Accounting and Auditing Standards for Islamic Financial Institutions yang dikeluarkan AAOIFI secara internasional dan PSAK No. 59 atau yang terbaru PSAK 101-106 di Indonesia. Hal ini dapat dilihat misalnya dalam tujuan akuntansi syari'ah aliran pragmatis yang masih berpedoman pada tujuan akuntansi konvensional dengan perubahan modifikasi dan penyesuaian berdasarkan prinsip-prinsip syariah. Tujuan akuntansi di sini lebih pada pendekatan kewajiban, berbasis entity theory dengan akuntabilitas terbatas.

Bila ditinjau lebih jauh, regulasi mengenai bentuk laporan keuangan yang dikeluarkan AAOIFI misalnya, disamping mengeluarkan bentuk laporan keuangan yang tidak berbeda dengan akuntansi konvensional (neraca, laporan laba rugi dan laporan aliran kas) juga menetapkan beberapa laporan lain seperti analisis laporan keuangan mengenai sumber dana untuk zakat dan penggunaannya, analisis laporan keuangan mengenai earnings atau expenditures yang dilarang berdasarkan syari'ah, laporan responsibilitas sosial bank syariah, serta laporan pengembangan sumber daya manusia untuk bank syariah (Harahap 2008). Ketentuan AAOIFI lebih diutamakan untuk kepentingan ekonomi, sedangkan ketentuan syariah, sosial dan lingkungan merupakan ketentuan tambahan. Dampak dari ketentuan AAOIFI yang longgar tersebut, membuka peluang perbankan syari'ah mementingkan aspek ekonomi daripada aspek syariah, sosial maupun lingkungan.

Penelitian yang dilakukan Hameed dan Yaya (2003) yang menguji secara empiris praktik pelaporan keuangan perbankan syariah di Malaysia dan Indonesia. Berdasarkan standar AAOIFI, perusahaan di samping membuat laporan keuangan, juga diminta melakukan pengungkapan analisis laporan keuangan berkaitan sumber dana zakat dan penggunaannya, laporan responsibilitas sosial dan lingkungan, serta laporan pengembangan sumber daya manusia. Tetapi hasil temuan Hameed dan Yaya (2003) menunjukkan bank-bank syariah di kedua negara belum melaksanakan praktik akuntansi serta pelaporan yang sesuai standar AAOIFI.

Terdapat lima kemungkinan mengapa laporan keuangan tidak murni dijalankan sesuai ketentuan syariah. Pertama, hampir seluruh negara muslim adalah bekas jajahan Barat. Akibatnya masyarakat muslim menempuh pendidikan Barat dan mengadopsi budaya Barat. Kedua, banyak praktisi perbankan syariah berpikiran pragmatis dan berbeda dengan cita-cita Islam yang mengarah pada kesejahteraan umat. Ketiga, bank syariah telah berdiri dalam sistem ekonomi sekularis-materialis-kapitalis. Keempat, orientasi Dewan Pengawas Syari'ah lebih menekankan formalitas fiqh daripada substansinya. Kelima, kesenjangan kualifikasi antara praktisi dan ahli syariah. Praktisi lebih mengerti sistem barat tapi lemah di syariah (Harahap 2008).

Aliran Akuntansi Syariah idealis di sisi lain melihat akomodasi yang terlalu "terbuka dan longgar" jelas-jelas tidak dapat diterima. Beberapa alasan yang diajukan misalnya, landasan filosofis akuntansi konvensional merupakan representasi pandangan dunia Barat yang kapitalistik, sekuler dan liberal serta didominasi kepentingan laba. Landasan filosofis seperti itu jelas berpengaruh terhadap konsep dasar teoritis sampai ben- 
tuk teknologinya, yaitu laporan keuangan. Keberatan aliran idealis terlihat dari pandangannya mengenai Regulasi baik AAOIFI maupun PSAK No. 59, serta PSAK 101-106, yang dianggap masih menggunakan konsep akuntansi modern berbasis entity theory (seperti penyajian laporan laba rugi dan penggunaan going concern dalam PSAK No. 59) dan merupakan perwujudan pandangan dunia Barat (Mulawarman 2006a, 2006b).

Tujuan laporan keuangan akuntansi syariah dalam PSAK syariah masih mengarah pada penyediaan informasi. Hal yang membedakan PSAK syariah dengan akuntansi konvensional, adanya informasi tambahan berkaitan pengambilan keputusan ekonomi dan kepatuhan terhadap prinsip syariah. Berbeda dengan tujuan akuntansi syariah idealis (filosofis-teoritis), mengarah akuntabilitas yang lebih luas. Konsep dasar teoritis akuntansi yang dekat dengan nilai dan tujuan syariah menurut aliran idealis adalah enterprise theory, karena menekankan akuntabilitas yang lebih luas. Berbeda dengan pemikiran shariate enterprise theory dilandasi premis yang mengatakan bahwa manusia adalah khalifatullah fil ardh yang membawa misi menciptakan dan mendistribusikan kesjahteraan bagi seluruh manusia dan alam. Oleh karena itu, shariate enterprise theory ini mendorong untuk menwujudkan nilai keadilan terhadap manusia dan lingkungan alam (Triyuwono, 2009: 393).

\section{METODE}

Penelitian ini menggunakan paradigma interpretif dengan pendekatan fenomenologi. Burrell and Morgan (1979) memaparkan bahwa sama halnya dengan paradigma fungsionalis, paradigma interpretif menganut sosiologi keteraturan, tetapi menggunakan pendekatan subjektifisme dalam analisis sosialnya, sehingga hubungan mereka dengan sosiologi keteraturan bersifat implisit/tersirat. Lebih lanjut tentang pendekatan yang digunakan dalam penelitian ini, Burrell and Morgan (1979) membagi pandangan dalam paradigma interpretif menjadi fenomenologi transedental dan eksistensial. Fenomenologi transendental/murni ini menghubungkan antara kesadaran dengan fenomena dunia. Husserl memperkenalkan istilah "intersubjectivity" untuk menunjukkan bagimana ego transenden menghasilkan ego lain sebagai mitra sejajar dalam komunitas intersubjektivitas, yang menjadi landasan untuk 'objektivitas'. Sedangkan fenomenologi eksistensial (dikembangkan oleh Heideger, Sartre, Schutz) membagi perhatian bersama pada apa yang disebut Huseerl "life-world", untuk dunia pengalaman keseharian sebagai lawan realisme kesadaran transendental (Setiawan 2011).

Mengacu pada definisi tersebut, maka peneliti menggunakan pendekatan fenomenologi transedental, karena tujuan peneliti adalah untuk mengeksplorasi pandangan masyarakat tentang perbankan syariah dan akuntansi syariah. Sebelum melakukan penelitian empiris, kajian pustaka menjadi tahap awal bagi peneliti. Setelah itu, kemudian dilakukan penelitian empiris dengan memilih informan yang meliputi praktisi (pengelola lembaga keuangan), dewan penyusun standar (DSAS) dan akademisi (dosen dan mahasiswa). Pihak praktisi yang dipilih oleh peneliti adalah perwakilan dari beberapa bank umum syariah yang berlevel makro dan beberapa LKMS seperti BPRS dan BMT yang berlokasi di Malang dan Tulungagung.

\section{HASIL DAN PEMBAHASAN}

Bukan lagi rahasia umum bahwa di dalam transaksi muamalah syariah antara teori dan praktik sering terjadi ketidaksinkronan. Sebuah teori atau model disusun sesempurna mungkin dengan tujuan untuk menghindari kemungkinan-kemungkinan terjadinya kecurangan. Sayangnya, "kesempurnaan" penyusunan model ini dihancurkan oleh fenomena penyimpangan teori syariah dalam praktik di lapangan. Perbedaan kondisi lapangan serta faktor sumber daya manusia, diduga menjadi penyebabnya. Ketidaksinkronan ini ternyata terjadi juga pada implementasi model laporan keuangan versi PSAK syariah yang telah diterbitkan oleh IAI pada tahun 2011. Ketidaksesuaian antara standar PSAK syariah dan implementasinya pada perbankan, menjadi salah satu sasaran kritik bagi para pemikir/pengamat syariah, khususnya PSAK nomor 100 tentang Kerangka Dasar Penyusunan dan Penyajian Laporan Keuangan serta nomor 101 tentang Penyajian Laporan Keuangan Syariah. Sebagai sebuah produk dari hasil pemikiran manusia yang menginginkan kondisi yang "sempurna", peluang terjadinya deviasi antara standar dan praktik atas PSAK syariah tidak dapat dihindari. Hal ini disampaikan oleh Bapak A, salah satu anggota DSAK IAI Jawa Timur, sebagai berikut: 
"Sebenarnya mbak, apa yang terjadi pada praktik perbankan sekarang ini, berbeda jauh dengan standar yang kami rumuskan. Beberapa contoh bentuk penyimpangan terlihat dari praktik penggunaan proyeksi untuk menentukan besarnya kucuran kredit (time value of money), kemudian pada transaksi mudharabah, ketika terjadi force majeur pihak ketiga, seharusnya yang menanggung adalah pihak perbankan, tapi dalam praktiknya tetap pengusaha sebagai pihak ketiga yang menanggung kerugiannya. Padahal di dalam aturan PSAK syariah, hal tersebut tidak diperbolehkan".

Kita sebagai pihak eksternal dari komunitas perumus model laporan keuangan PSAK syariah, akan memberikan justifikasi bahwa yang patut dipersalahkan adalah lembaga keuangan syariah yang tidak melaksanakan pakem yang telah ditetapkan. Masyarakat selama ini berasumsi bahwa tidak terlaksananya PSAK syariah dikarenakan oleh faktor sumber daya manusia yang memang kurang peduli (aware) dengan bidang syariah. Alasan lain diduga karena "standar" yang dilahirkan memang tidak implementatif, sehingga teori atau standar dianggap sebagai aturan yang berlaku di surga (surgawi), sedangkan yang diperlukan praktisi adalah teori yang dapat dipraktikkan di dunia (duniawi). Alasan-alasan di atas, ternyata linier dengan argumen yang disampaikan oleh Bapak A bahwa:

"Kalau menurut saya, alasan mengapa di negeri kita ini syariah kurang bisa berkembang selayaknya Negara lain seperti Malaysia, adalah karena masyarakat yang kurang begitu aware. Ketika pemimpin sebuah institusi perbankan syariah tidak aware dengan syariah, maka mekanisme keseluruhan di dalamnya pasti juga tidak akan syariah meski kita sudah menutup celah kemungkinan dilakukannya kecurangan melalui perumusan model laporan keuangan syariah seperti yang tertuang di dalam PSAK syariah".

Pernyataan tersebut adalah pandangan dari pihak penyusun standar yang me- nilai bahwa kegagalan impelementasi PSAK syariah adalah karena faktor SDM. Beliau sangat menyadari bahwa standar PSAK syariah yang telah diterbitkan, ternyata tidak sepenuhnya implementatif. Menurutnya, ada 3 faktor yang berpengaruh pada keberhasilan implementasi standar, yaitu regulasi, pelaksana (SDM) dan masyarakat. Regulasi dalam hal ini terkait dengan regulasi yang ditetapkan oleh pemerintah (Bank Indonesia) tentang pelaksanaan operasional lembaga keuangan syariah. Lembaga keuangan syariah sebagai pelaksana standar, hanya berwenang melaksanakan aktivitas pendanaan dan pembiayaannya dalam koridor regulasi pemerintah tersebut. Oleh karena itu, jika regulasi yang dilahirkan pemerintah masih jauh dari ketentuan-ketentuan syariah, maka dapat dipastikan operasional lembaga perbankan syariah yang tersebar di seluruh Indonesia menjadi jauh pula dari syariah. Selanjutnya, faktor SDM juga menjadi penentu sejauh mana sebuah standard dapat diimplementasikan sesuai dengan teorinya. Meskipun suatu standar telah disusun sesempurna mungkin, namun ketika SDM, khususnya pemimpin lembaga tidak memiliki kompetensi syariah yang memadai, atau belum mampu menginternalisasikan syariah dalam pola pikirnya, maka pasti masih ada saja celah untuk kembali ke praktik konvensional. Faktor terakhir yang berkontribusi pada keberhasilan implementasi standar adalah masyarakat sebagai konsumen laporan keuangan yang disusun oleh lembaga keuangan syariah. Secara tidak langsung, masyarakat ini berperan sebagai pengamat terhadap keseuaian antara substansi standar dengan sistem syariah serta menilai keseuaian praktik dengan standar syariahnya. Inilah yang terjadi saat ini, dimana mulai bermunculan para pemikir syariah dan praktisi yang mengkritisi baik standar PSAK syariah yang diluncurkan oleh IAI maupun kritik terhadap kesenjangan antara standard an praktik syariah.

Seperti yang dilangsir dari zonaekis. com, disampaikan bahwa krisis sumber daya manusia (SDM) menjadi salah satu tantangan berat di Indonesia dan global. Di Dubai dan Arab Saudi yang menjadi pusat perbankan syariah dunia, mayoritas pekerjanya berasal dari Malaysia dan Pakistan. Keterbatasan tersebut yang menjadi kendala perkembangan ekonomi syariah di Indonesia. Pernyataan ini didukung oleh Pengamat Ekonomi Syariah Unair, Zakik Irham MSE, 
yang berpendapat bahwa secara umum tingkat pemahaman mengenai bagaimana mekanisme usaha dalam penentuan bagi hasil, karakteristik, produk dan jasa, serta akad-akad bank syariah dinilai masih rendah. Beliau menambahkan, masih minimalnya pemahaman konsep syariah di kalangan masyarakat Indonesia ini sangat ironis, karena mayoritas masyarakatnya memeluk agama Islam. Sementara di sisi lain, konsep ekonomi syariah kini semakin mendunia yang terlihat dari diadopsinya prinsip ekonomi syariah Negara adikuasa Amerika Serikat usai mengalami krisis. Singapura pun bertekad mendeklarasikan diri sebagai Negara dengan sistem ekonomi Syariah terbesar di Asia Tenggara, mengalahkan Malaysia yang telah lama maju ekonomi syariahnya. Namun demikian, menurut International Monetary Fund (IMF), pada tahun 2011 perbankan syariah Indonesia akan mengalami kemajuan pesat dan akan menjadi satu-satunya negara berkembang yang maju dalam perkembangan bank syariahnya. Harapan ini bukanlah hanya sekedar wacana, hanya jika "capacity building diintensifkan untuk mengembangkan bank syariah", demikian diungkapan oleh direktur retail Bank PT. Bank Muamalat (Tbk), Adrian A. Gunadi.

Dalam menggali informasi tentang kesenjangan antara teori dan praktik PSAK syariah, selain menggunakan informan pihak penyusun standar, peneliti juga melibatkan pihak praktisi, seperti yang telah disampaikan pada bab metodologi penelitian. Bapak $\mathrm{B}$, seorang praktisi yang menjabat sebagai direktur bank Mega Syariah cabang Madura selama 8 tahun terakhir dimana sebelumnya beliau menjabat sebagai direktur bank konvensional BCA selama hampir 10 tahun menjadi informan pertama. Menanggapi tentang fenomena kesenjangan antara teori dan praktik PSAK syariah, beliau memaparkan bahwa:

"ketika saya diangkat menjadi direktur bank syariah mega mbak, saya ditanya oleh dirut waktu itu, tentang apa tujuan institusi ini ketika saya diangkat sebagai direoktur baru. Apakah profit oriented, sosial atau seperti apa? Ya saya jawab profit oriented, karena kalo sosial ya gak jalan mbak".

Syariah yang dimaknai bukan sekedar profit oriented, namun juga falah oriented yang berarti bertujuan untuk kemakmu- ran di dunia dan kebahagiaan di akhirat, rasanya tidak sejalan dengan makna syariah dalam mindset beliau. Menganalisis dari pemaparan Bapak B di atas, dapat peneliti simpulkan bahwa tidak ada perbedaan yang substansial antara sistem syariah dan konvensional dalam menjalankan lembaga keuangan syariah. Hal terpenting menurut beliau adalah bagaimana lembaga tersebut dapat going concern dengan profit yang tinggi. Sistem syariah yang "dipaksakan" diinsersikan ke dalam sistem konvensional yang lebih settle, tidak akan menciptakan perubahan secara holistik. Syariah tidak hanya dimaknai dengan sekedar menghindari riba atau syariah bukan pula sedangkan hanya dengan melaksanakan bagi hasil, namun lebih mendasar dari itu. Perbedaan kerangka konseptual (framework) menjadi dasar yang membedakan antara keduanya.

Dari sepenggal penjelasan Bapak B di atas, menjadi benar apa yang disampaikan oleh Bapak A bahwa permasalahan implementasi syariah terletak pada SDM. Hal ini mengindikasikan bahwa dugaan bahwa PSAK syariah sebenarnya telah menerapkan prinsip-prinsip syariah, namun dalam implementasinya yang melanggar ketentuan standar tersebut. Sekali lagi, pernyataan tersebut masih bersifat dugaan sampai peneliti memberikan pertanyaan tentang kesesuaian antara teori dan praktik. Ketika seorang pemimpin hanya berorientasi pada laba, maka dapat dipastikan mekanisme operasional institusi yang dipimpinnya menjadi kapitalis. Bapak Amemperkuat pernyataannya dengan

“...meskipun kami sudah membuat standar dengan sempurna, tapi kalau fokus praktisi hanya pada profit oriented, pasti akhirnya terjadi anomali antara standard dan praktik".

Oleh karena itu, selalu saja terdapat celah untuk kembali ke sistem konvensional untuk sekedar berburu profit, ketika pelakunya masih belum mampu memahami dan menginternalisasikan syariah secara holistik. Alasan lain mengapa akuntansi syariah masih belum bisa lepas sepenuhnya dari sistem konvensional, diutarakan oleh Antonio (2011) yang menyatakan bahwa lahirnya sistem konvensional yang terlebih dahulu, menjadikan sistem ini lebih "settle" dibandingkan dengan syariah. Sedangkan sistem syariah yang dicetuskan pada tahun 1940-an yang ditandai dengan berdirinya 
Myt-Ghamr Bank di Mesir, sampai saat ini masih dalam proses penyempurnaan terus menerus. Pada tataran konsep, telah banyak ditemukan pemikiran-pemikiran baru dalam bidang syariah yang berkontribusi pada penyempurnaan standar syariah dalam bidang akuntansi, seperti Baydoun dan Willett, Ross Hanifa, Sofyan Syafri Harahap, Syafii Antonio, Yuslam Fauzi, Ahmad Marjuki, Adityawarman Karim, Iwan Triyuwono dan Aji Dedi Mulawarman.

Dikutip dari Chariri (2011) yang menyampaikan bahwa praktik akuntansi konvensional di Indonesia dapat ditelusur pada era penjajahan Belanda sekitar tahun 1642 (Soemarso 1995). Jejak yang jelas berkaitan dengan praktik akuntansi konvensional di Indonesia dapat ditemui pada tahun 1747. Pada era ini, Belanda mengenalkan sistem pembukuan berpasangan (double-entry bookkeeping) sebagaimana yang dikembangkan oleh Luca Pacioli. Keberadaan sistem akuntansi konvensional yang dinilai lebih "settle", bukan berarti kemudian akuntansi syariah sebagai pendatang baru harus mengikuti sistem konvensional, seperti yang disampaikan oleh Bapak A dalam wawancara dengan peneliti. Beliau menyampaikan bahwa:

"akuntansi syariah tidak dapat begitu saja dimasuki oleh sistem konvensional, karena memang ada beberapa hal yang dilarang Islam terkait dengan prinsip-prinsip konvensional seperti bunga dan Time Value of Money".

Akuntansi konvensional terlahir dengan sistemnya yang kapitalis. Munculnya akuntansi syariah, diharapkan menjadi solusi atas sistem konvensional yang sampai saat ini dinilai masih terdapat banyak kekurangan. Munculnya ketidakadilan dalam perputaran sistem ekonomi yang sarat dengan eksploitasi manusia, penindasan dan kerusakan alam menjadi efek samping atas implementasi sistem akuntansi konvensional.

Peneliti mencoba untuk mengeksplorasi praktik syariah dalam LKMS di salah satu BMT di Malang melalui pengelolanya. Dari paparan sang manajer, menurut penilaian beliau praktik syariah yang selama ini dijalankan telah sesuai dengan prinsip syariah. Demikian pula dari penilaian peneliti bahwa tidak ada permasalahan dengan praktik syariah di dalam BMT tersebut,namun ada hal lain yang diungkapkan beliau terkait kesulitannya dalam hal penyusunan laporan keuangan. Minimnya keahlian (skill) yang dimiiki personil pengelola BMT tentang penyusunan laporan keuangan telah membuat model laporan keuangan yang disusunnya tidak informatif ${ }^{6}$. Ketika peneliti menanyakan tentang standar PSAK syariah khususnya nomor 101 tentang Penyajian Laporan Keuangan Syariah, sang manajer langsung menyampaikan bahwa penyusunan laporan keuangannya tidak disusun sesuai dengan pedoman tersebut. Alasan yang diungkapkan adalah faktor minimnya skill untuk memahami dan menerapkan PSAK syariah nomor 1 tersebut. Ternyata kondisi ini tidak hanya dialami oleh BMT yang dipilih peneliti sebagai informan tersebut, namun berdasarkan informasi beliau sebagai pihak praktisi yang sering melakukan koordinasi dengan seluruh BMT se-Malang Raya menyampaikan bahwa tidak ada satupun laporan keuangan mereka yang disusun seperti PSAK syariah 101. Bagi mereka standar tersebut tidak implementatif karena tidak sesuai dengan kebutuhan.

Berbeda dengan praktisi BMT di atas, Bapak D, yang mengungkapkan bahwa PSAK menjadi standar yang tidak implementatif karena tidak sesuai dengan kebutuhan LKMS yang cenderung lebih sederhana dibandingkan dengan bank umum syariah, praktisi lain yang ditemui peneliti yaitu manajer koperasi syariah yang terletak di kota Tulungagung. Koperasi syariah ASRI yang berdiri selama tiga tahun ini, menunjukkan kinerja yang memuaskan. Terbukti dari kredit macet yang hanya menunjukkan prosentase sebesar $0,26 \%$ dari total aktiva, kemudian besarnya dana yang tersalurkan sebesar $80 \%$ dari total aktiva dalam bentuk pembiayaan murabahah dan mudharabah ${ }^{7}$, dan rasio kewajiban lancar terhadap aktiva lancar sebesar 0,47\%. Dari perhitungan secara garis besar tersebut menunjukkan bahwa koperasi syariah ASRI memiliki kinerja yang baik $^{8}$. Keinginan peneliti un-

6. Laporan keuangan yang disusun hanya terdiri dari neraca, laba rugi dan rinciannya. Agar laporan dapat dipahami oleh orang awam (di luar pengelola koperasi syariah ASRI), seharusnya dilengkapi pula oleh laporan kualitatif. Selain itu, laporan lain diluar neraca dan laba rugi seperti laporan arus kas seharusnya menjadi komponen laporan keuangan.

7. Sebagian besar LKMS intensitas transaksi yang terjadi adalah murabahah dan mudharabah.

8. Perhitungan tersebut tentunya merupakan beberapa indikator dari sekian banyak perhitungan yang digunakan ketika menilai "kesehatan" sebuah lembaga keuangan 
tuk mengeksplorasi LKMS ini menjadi lebih agresif. Dari hasil interview dengan sang manajer, peneliti dapat menyimpulkan bahw abeliau adalah sosok yang sangat aware dengan syariah. Pemahamannya tentang syariah, dmilikinya skill penyusunan laporan keuangan dan pengetahuan akan seluk beluk praktik keuangan konvensional dan syariah membuat lembaga ini menunjukkan pertumbuhan yang signifikan dari tahun ke tahunnya. Hal pertama yang disampaikan beliau adalah "bank umum syariah itu tidak syariah". Melihat kembali perjalanan karier beliau yang pernah menjajaki atmosfer perbankan konvensional, ungkapan tersebut menjadi informasi yang akurat. Dua hal utama yang disoroti beliau adalah masalah loss sharing yang ternyata tetap memaksa nasabah untuk membayar minimal pengembalian meskipun karena terjadi force majeur dan pengakuan pendapatan dan masih digunakannya proyeksi keuangan untuk syarat pengajuan pinjaman dana. Menurut beliau bank umum syariah masih menggunakan pola pikir profit orientedsebagai tujuan utamanya. Pernyataan ini in line dengan yang disampaikan oleh Bapak B di atas bahwa ketika beliau menjabat sebagai kepala cabang salah satu bank syariah, pencapaian laba semaksimal mungkin tetap menjadi tujuan utamanya, bukan profit dan falah seperti yang disyaratkan oleh syariah.

Di sela panasnya diskusi, beliau kemudian menunjukkan model laporan keuangan yang disusunnya. Tampak tidak sama persis dengan model laporan keuangan yang disyaratkan dalam PSAK 101. Namun demikian beliau memodifikasi PSAK 101 dengan beberapa penyesuaian ${ }^{9}$. Beliau menyampaikan bahwa:

"model laporan keuangan yang ada di PSAK syariah itu menurut saya masih belum syariah secara total. Terlihat di sana, dalam laporan sumber dan pengunaan dana kebajikan masih mencampuradukkan sumber halal dan haram, sudah begitu didistribusikan bersama ke masyarakat sebagai dana sosial. Selain itu, ada ketidakadilan juga didalam mekanisme bagi rugi (loss sharing)".

9. Penyesuain ini berupa gurangan akun dan loss sharing pada

penambahan akun, penpenyesuaian mekanisme transaksi mudharabah.
Tidak hanya berhenti dari penjelasan ketidaksyariahan PSAK syariah 101, beliau menjelaskan pula mengapa laporan keuangan yang disusunnya tidak terdiri dari sembilan komponen yaitu neraca, laporan laba rugi, laporan arus kas, laporan perubahan ekuitas, laporan perubahan dana investasi terikat, laporan rekonsiliasi pendapatan dan bagi hasil, laporan sumber dan penggunaan dan zakat, laporan sumber dan penggunaan dana kebajika dan catatan atas laporan keuangan, namun beliau hanya menyusun neraca, laporan laba rugi, dan rincian neraca dan laba rugi dalam satu laporan keuangannya. Alasan yang disampaikan adalah karena faktor kerumitan dan kekompleksan jika LKMS disyaratkan untuk mengikutinya. Di sisi lain, lembaga yang berbadan hukum koperasi tidak ada kewajiban untuk melaporkan ke stockholders layaknya bank umum syariah karena kepentingan menarik investor. Satu pernyataan dari beliau yang menarik di saat akhir wawancara kami,
"Sia-sia kita susun laporan keuangan yang serumit seperti PSAK syariah itu. Orang di Di- nas Koperasi sebagai pihak yang menerima pertanggungjawaban koperasi kurang memahami ten- tang laporan keuangan. Saya su- sun laporan keuangan sesederha- na ini saja mereka tidak mengerti makna laporan keuangan (kuanti- tatif) yang saya sampaikan. Lapo- ran yang mereka lihat hanyalah deskripsi kualitatif, sedangkan laporan keuangan akhirnya han- ya menjadi formalitas saja".

Seperti yang telah dipaparkan peneliti dalam metodologi penelitian bahwa informan yang dipilih bukan hanya dari pihak praktisi dan penyusun standar, namun akademisi pun diikutsertakan. Salah seorang dosen ${ }^{10}$ menyampaikan pula suatu hasil pengamatan berkunjung ke bank syariah ada seorang nasabah yang ingin mengajukan pinjaman. Ternyata pihak bank meminta si nasabah untuk menyiapkan laporan proyeksi selama 10 tahun ke depan. Fenomena ini ditunjang

10. Dalam sebuah perkuliahan "Sosio Spiritual Akuntansi Syariah" yang diampu oleh Dr. Aji Dedi Mulawarman, dosen jurusan akuntansi Fakultas Ekonomi dan Bisnis Universitas Brawijaya, yang lebih banyak berkonsentrasi pada bidang akuntansi syariah. 
dengan pengkajian sebuah artikel karangan Weil (1990) yang mengupas habis penggunaan Time Value of Money (TVM) pada beberapa aktivitas, seperti dana pensiun. Senada dengan yang dikutip Mulawarman (2006a, 2006b) dari Weil (1990), menjelaskan sebenarnya akuntansi selalu menggunakan time value of money berkenaan penentuan waktu (timing) terhadap transaksi nilai investasi serta kepastian penilaian yang dipengaruhi nilai uang. Beralih dari mengomnetari praktik LKS, beliau menyampaikan pula bahwa akuntansi syariah sama halnya dengan akuntansi konvensional. Satu pernyataan beliau yang sangat menarik disampaikan, "dalam merumuskan akuntansi syariah, seharusnya syariah yang masuk ke akuntansi, bukan sebaliknya akuntansi yang masuk syariah". Ketidaksyariahan akuntansi syariah kini terjadi adalah karena akuntansi yang memasuki syariah, jadi konsep syariah "dipaksa" untuk mengikuti akuntansi konvensional yang selama ini telah tertancap di dalam pemikiran masyarakat luas.

Dosen lain ${ }^{11}$ yang berlatar belakang dari ekonomi pembangunan, dalam suatu diskusi ringan, beliau membenarkan penilaian bahwa perbankan syariah tidak syariah. Hanya namanya saja yang syariah, namun praktiknya belum bisa lepas dari pengaruh syariah. Penggunaan jumlah terendah yang memaksa nasabah untuk melunasi dana pinjaman meskipun dalam kondisi mengalami kerugian karena ketidaksengajaannya, telah membuat skema perbankan syariah semakin jauh dari konsep syariah yang sesungguhnya.

Masih pada informan akademisi, peneliti pun berburu informasi tentang penyimpangan praktik perbankan syariah dan akuntansi syariah dari konsep syariah yang holistik. Beberapa mahasiswa/i pascasarjana Jurusan Akuntansi Fakultas Ekonomi dan Bisnis Universitas Brawijaya, menjadi sasaran informan. Salah satu diantara mereka menceritakan pengalamannya ketika berhadapan dengan pihak bank syariah ketika melakukan pinjaman dana. Senada dengan yang disampaikan oleh salah satu dosen di atas, nasabah diminta untuk menyiapkan

11. Diskusi berlangsung pada saat kuliah tamu dan konsultasi publik dengan tema "Mengkritisi UU no.23 tahun 2011 tentang Pengelolaan Zakat", peneliti berdiskusi dengan salah satu dosen prodi Ekonomi Islam jurusan Eonomi Pembangunan Fakultas Ekonomi dan Bisnis Universitas Brawijaya, Dr. Asfi Manzilati, SE., ME. proyeksi keuangan selama beberapa tahun ke depan. Mahasiswa lain menyampaikan bahwa PSAK syariah 102-106 tidak syar'i. Ternyata sampai interview dilakukan, telah ada beberapa mahasiswa yang telah mengkritisi PSAK syariah mulai dari 101-106 dari sisi ketidaksyar'iannya. Tidak berhenti di situ, mahasiswa yang saat ini sedang menulis Tesis berusaha melanjutkan upaya kritis atas PSAK syariah dari sisi analisis yang berbeda. Sebuah kontribusi yang luar biasa untuk membuat praktik perbankan syariah dan akuntansi syariah sesuai dengan syariat Islam.

\section{SIMPULAN}

Dari hasil penelitian empiris di atas, dapat disarikan menjadi dua kesimpulan, yaitu terdapat 2 faktor pemicu yang menjadi alas an mengapa perbankan syariah masih diidentikkan dengan perbankan konvensional, yaitu dari sisi teoritis dan praktis.

Ditinjau dari sisi teoritis, PSAK syariah sebagai dasar pedoman pencatatan dan pelaporan dipandang sebagai aturan yang kurang implementatif. Terlebih lagi bagi LKMS yang dituntut untuk menyusun laporan keuangan dengan berpedoman pada PSAK syariah, sementara sebagian besar pedoman yang tersurat dalam peraturan tersebut tidak relevan dengan kondisi riil yang dihadapi.

Sementara dari sisi praktis, ternyata masih banyak dijumpai SDM perbankan syariah yang kurang bahkan tidak memahami hakikat syariah dalam praktik akad-akad transaksi syariah. Dengan demikian, meskipun standard produk dan mekanisme akad tidak sesuai dengan ketentuan syariah, tidak pernah ada koreksi dari pengelola. Informasi yang mereka sampaikan kepada nasabah hanya sekedar penyampaian tanpa pemahaman alias sekedar pengguguran kewajiban atas job description-nya. Hal ini diperparah oleh keengganan mereka untuk memahami syariah secara holistic, sehingga jika kondisi seperti ini diacuhkan terus-menerus, maka kejayaan umat seperti yang diharapkan dalam Islam akan sulit tercapai.

\section{DAFTAR RUJUKAN}

Anonim. 2012."Ada Riba di Bank Syariah". Tabloid Syariah. Diakses pada $3 \mathrm{Mei}$ 2012 dengan situs http://www.syariah.info/2012/02/08/ada-riba-dibank-syariah. 
Anggadini, S. D. 2010."Bentuk Kecurangan pada Lembaga Keuangan Syariah". Majalah Ilmiah UNIKOM . Vol.7 No.2, hal 193-198.

Antonio, S. 2001. Bank Syariah Dari Teori ke Praktik, Gema InsaniPress. Jakarta.

Burrell, G. dan G. Morgan. 1979. Sociological Paradigms and Oragnisational Analysis. Ashgate Publishing Company. USA.

Capra, M.U dan H. Ahmed. 2002. Corporate Governance in Islamic Financial Institution. Jeddah Ocasional Paper IDB.

Harahap, S. S. 2001. Kritik Terhadap PSAK Perbankan Syariah IAI dan AAOIFI. $\mathrm{Me}$ dia Riset Akuntansi, Auditing dan Informasi. Vol.1 No.3, hal 87-105

IAI. 2002. Kerangka Dasar Penyusunan dan Penyajian Laporan Keuangan Bank Syariah. Jakarta

Kamayanti, A. dan Setya, P. 2008. Persepsi Nasabah dalam Memilih Bank Syariah dan Bank Konvensional di Sidoarjo. Seminar STIE Mahardhika dan Bank Muamalat.

Karim, A.A. 2006. Bank Islam; Analisis Fiqih dan Keuangan. Edisi tiga. PT Raja Grafindo Persada. Jakarta.

Muhammad. 2002. Pengantar Akuntansi Syariah. Salemba Empat. Jakarta.

Mulawarman, A. D. 2006a. Menyibak Akuntansi Syariah. Kreasi Wacana. Yogayakarta.

Mulawarman, A. D. 2006b. Rekonstruksi Teknologi Integralistik Akuntansi Syariah: Shari'ate Value Added Statement. Simposium Nasional Akuntansi IX.
Mulawarman, A. D. 2008. Tazkiyah Peradaban. Diakses di www.ajidedim.wordpress.com pada 20 September 2011.

Nurhayati, S. Dan Wasilah. 2009. Akuntansi Syariah di Indonesia, Edisi 2. Penerbit Salemba Empat. Jakarta.

Primasari, N.H. 2010. Faktor-Faktor yang Menghambat Perkembangan Perbankan Syariah. Staf Pengajar Fakultas Ekonomi Universitas Muria Kudus.

Setiawan, A.R. 2011. Tinjauan Paradigma Penelitian: Merayakan Keragaman Pengembangan Ilmu Akuntansi. Jurnal Akuntansi Multiparadigma. Vol.2 No.3, hal 402-417.

Setiawan, A.B. 2006. "Perbankan Syariah; Challenges dan Opportunity untuk Pengembangan di Indonesia". Jurnal Kordinat. Edisi: Vol.VIII No.1.

Sulistiyo, A.B. 2010. Memahami Konsep Kemanunggalan dalam Akuntansi: Kritik atas upaya Mendekonstruksi Akuntansi Konvensional menuju akuntansi syariah dalam bingkaiTasawuf. Jurnal Akuntansi Universitas Jember. Vol. 8 No. 1, hal 13-24

Triyuwono, I. 2002. Perspektif, Metodologi, dan Teori Akuntansi Syariah. Raja Grafindo Persada, Jakarta.

Triyuwono, I. 2003. "Sinergi Oposisi Biner: Formulasi Tujuan Dasar Laporan Keuangan Akuntansi Syari'ah". IQTISAD Journal of Islamic Economics. Vol. 4, No. 1, Muharram 1424 H,hal 7990.

Weil, R.L. 1990. "Role of The Time Value of Money in Financial Reporting". Accounting Horizon. December, hal 46-67. 